\title{
AN INNOVATIVE PATTERN TO DESIGN NEW BUSINESS MODELS IN THE MACHINE TOOL INDUSTRY
}

\author{
Giacomo Copani \\ Politecnicodi Milano, giacomo.copani@polimi.it \\ Silvia Marvulli \\ Institute of Industrial Technologies and Automation-CNR, silvia.marvulli@itia.cnr.it \\ Lorenzo Molinari Tosatti \\ Institute of Industrial Technologies and Automation-CNR, lorenzo.molinari@itia.cnr.it
}

\begin{abstract}
Since some years, European machine tool companies are facing a turbulent market, where Asiatic competitors are becoming more and more aggressive. In such context, technology improvement is not anymore sufficient to preserve their market position: the evolution of their business model towards the offer of value added services will be a fundamental key for future success. This paper, realised within "Next Generation Production Systems" FP6 European Project, proposes an innovative operative pattern guiding machine tool companies in the business model innovation decisions.
\end{abstract}

Keywords: Business model, Machine tool industry, customer-supplier relationships

\section{INTRODUCTION}

Business model innovation is an innovative concept in the European machine tool industry, which represents more than $40 \%$ of the worldwide value of machine tools' production and counts about 150,000 employees (Cecimo, 2006). In this sector, equipment suppliers are traditionally oriented to the offering of production systems with a limited number of additional product related services (e.g. installation, training, etc.). The relationship between customers and suppliers are mainly limited to the sales operative phase (transaction based relationship) and machine tool builder core competencies are related to the engineering and production of machines. In the past, such an approach allowed European machine tool companies to get and preserve a strong position in their sectors (Mathe-Portioli Staudacher, 2004). In recent years, the European industry competitiveness has been strained by the increased turbulence of the business arena, determined by new aggressive competitors from emerging Countries (Windahl et al. 2004, Gebauer et al., 2005).

To cope with this situation, companies should innovate their business models establishing more collaborative long-term relationships with their customers and offering value added services beyond the traditional technical ones (Windahl et al., 2004). In fact, the technological innovation does not represent anymore a differentiating strength point which companies can base their offer on (European Manufacturing Survey, 2005). Instead, the integration of value added services with the physical products (i.e. production systems) could guarantee a stable source of revenues, an increasing market demand and a competitive weapon not easily imitable (Cohen-Whang, 1997, Oliva-Kallenberg, 2003). 
Furthermore, service offerings incentivize the creation of sustainable long-term relationships with customers (Frambach et al., 1997).

Despite the unanimous agreement on the described innovation need, European machine builder companies are still far from reaching this goal (Lay, 2007). The main reasons have been identified in the lack of specific managerial culture and of operative tools supporting this complex change, which requires market, organizational, financial, and supply chain innovation (Copani et al., 2007 a). Current literature offers general theoretical addresses about business models, but available results are mainly derived from the world of internet based companies and, apart some recent exceptions, no structured managerial tool supporting strategic decisions exists. To cover this lack, a new frame to shape the relationships between machine tool builders and their customers, consisting of a multi-step methodology for the selection and design of the most appropriate business models, has been designed and presented in this paper.

In the next section the research methodology is briefly described. The third section is dedicated to the review of the existing literature on New Business Models in the machine tool industry, while the fourth and fifth sections describe the designed methodology and the results of the testing phase. In conclusion, some guidelines for future research in this field are provided.

\section{RESEARCH METHODOLOGY}

To develop the decision tool supporting the business model selection, a preliminary literature review on New Business Models has been carried out. The tool has been then designed, identifying the main decision phases that a company should face while selecting a business model. For each phase, the main possible variables that should be evaluated by a machine builder, together with their possible options, have been made explicit using the knowledge acquired from literature review on one side, and involving in the research some leading European machine builders on the other. Finally, the decision support tool has been tested in some real business case.

\section{LITERATURE REVIEW}

The topic of New Business Models referred to the machine tool sector has gained the attention of industrialists and management researchers only in recent years. Up to the beginning of the 2000's, technology was thought to be the main answer to respond to market needs and evolution. As a consequence, the research focus was mainly addressed to the development of production systems able to efficiently support companies in their production activities. The introduction and conceptualization of Reconfigurable Manufacturing Systems (Koren et al., 1999) paved the way for different collaborative approaches beyond the only production system technology. The "selling use" approach, where the supplier owns and operates the machine and the customer pays only for its use, was conceived by Franke et al., 2002 as the alternative to the traditional selling of the production system in case of high reconfigurability. Seliger et al., 2004 argued that adaptation services (e.g. maintenance, enlargement, rearrangement, modernization, etc.) are needed to enable the re-use of the system and "align" it to the exigencies of different customers. In line with this view, a specific strategy to implement and develop such services has been proposed in recent years (Scholz et al., 2007).

Focused on a customer-supplier relationship perspective, a new research stream on the service based supply of manufacturing capacity emerged (Urbani et al., 2002, Molinari 
Tosatti et al., 2002). Based on the possible scenario evolutions and on the different drivers determining the supply chain relationships (ownership, location, operating personnel, maintenance personnel, payment mode), a categorization scheme allowing the structured representation of different business models options has been proposed (Lay et al., 2003). Such scheme has been further detailed and enriched during the Mantys Project (Mantys, 2005 ) with the scope to supply machine builders with a matrix supporting the negotiation phase with customers.

The organizational transition from product to service in the value proposition of machine tool suppliers was the focus of the study of Oliva and Kallenberg, 2003, that provided a process model for developing service capabilities. The combination of products and services has also been taken into account by Windahl et al., 2004, referring to it as "integrated solution" as part of the growth strategies of companies in this sector. In the last years these research trends, and especially the shift from the technology to its use, have been integrated in the wider research stream of the Industrial Product Service System (IPS2). Different IPS2 for the machinery sector have been proposed, together with some criteria to differentiate them (revenue model, operating personnel, production responsibility, maintenance personnel, service request) (Meier-Kortmann, 2007).

As it can be noticed, the research results currently available to companies are mainly at strategic and conceptual level. The link between strategy and concrete operation practices is still missing, and this partly explains the slow adoption rate of New Business Models by European companies (Copani et al., 2007 a). One of the first attempts to overcome this lack has been the definition of specific financial guidelines supporting machine tool builders to identify the proper revenue model to be offered within an innovative service oriented value proposition (Copani et al., 2007 b). Unconventional financial methods, such as pay per part or per availability mechanisms, have been theorised in order to start a cultural change in the industry.

\section{PATTERN TO DESIGN NEW BUSINESS MODELS}

The main scope of the methodology presented in this paper is to support machine tool suppliers in the definition of potential innovative offerings to be proposed to their customers in a New Business Model environment. The methodology represents thus a powerful operative instrument guiding machine builders to take strategic and commercial decisions in order to gain competitiveness through non-technical innovation. The methodology consists of three sequential analysis-decision phases. For each of them, a pre-built database of options and of analysis criteria has been designed, so that the methodology is populated with a-priori defined contents. Such contents have been developed assessing the main possible market situations that a machine builder could face, both derived from the surveyed literature and, especially, from the involvement of leading European machine builder companies experienced with New Business Models.

The sequential phases are described in the following paragraphs.

\subsection{Identification of customers' business needs}

In the first phase the machine builder customer's needs are identified according to his specific company situation. In order to support such analysis, the following possible business needs have been recognized as the most frequent in the market:

- Reduction of costs, referred to production, logistics and maintenance.

- Increase of quality of the production process and of the final products. 
- Reduction of the lead time, including production, maintenance and logistics (procurement and delivery) time.

- Increase of productivity, defined as the ratio between the produced output and the inputs necessary for it.

- Increase of flexibility, defined as the capacity of the company to respond in a timely and costly effective manner either to internal or external changes, as variations in market requests.

- Reduction of risk, related to the production process (operating risk) or the logistic activities.

To detect which are the real customer business needs among those listed, the specific company situation has to be analyzed. A checklist has been made available for this, composed of 29 customer indicators in the following areas:

- Production process situation (low productivity, high production lead time, high scrap rates, low operational availability, high production costs, alternating capacity requirements, presence of bottle-necks).

- Workforce situation (skilled service workforce missing at customer's plant, low operational know-how).

- Production system situation (long reinvestment period, low flexibility, no or low exploitation of available machine features).

- Final Product situation (huge amount of product variants, small amount of product variants, short product cycles, low retooling frequency, cyclical industry, customer is a make-to-order manufacturer, production of prototypes/sample/trial parts, production of spare parts in end of service (life) cycle, unpredictable market prospect).

- Logistic process situation (high procurement costs, high delivery costs, high procurement time, high delivery time, high logistic risk).

- Maintenance process situation (high maintenance costs, high repair frequency, high repair time).

Starting from the indicators, criteria permitting to identify which are the possible customer's business needs have been imbedded in the methodology and are graphically represented with the coloured cells in Figure 1, which is an extract from the overall data base of indicators, business needs and criteria.

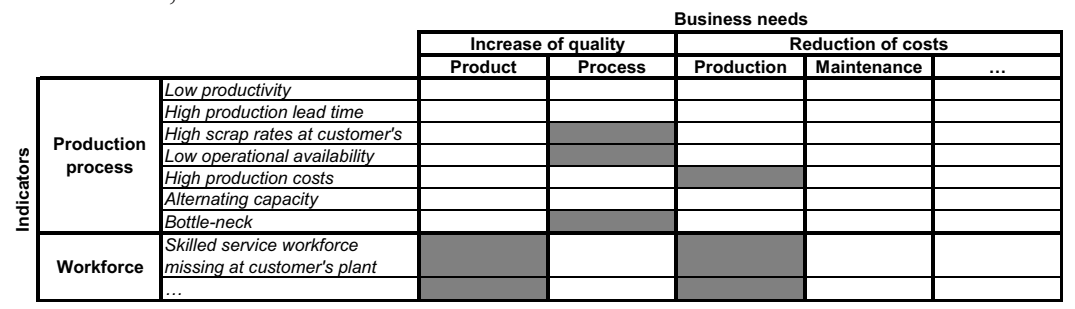

Figure 1. Extract from the table supporting customer's business needs identification

Since the customer condition is outlined by more than one indicator, multiple business needs among those described can be identified at the same time. Nevertheless, the value of this first phase consists of the restriction of the attention of the machine builder to some real problems of the customer, which are detected considering its whole productive and organisational situations. 


\subsection{Definition of the value propositions}

In the second step, the machine tool supplier has to define his value proposition to the customer in order to innovatively respond to the business needs detected in the previous phase. A value proposition represents the intentions of the machine builder while fulfilling customer requests; thus, it should include the technical proposition (the production system) and the additional value added services.

Nine innovative value propositions have been thought as a quite significant set of the existing industrial realities:

- offering concepts for levelling irregular and temporary customer capacity requirements;

- offering complete production service;

- offering procurement management;

- offering delivery management;

- providing availability guarantee;

- solving customer qualification deficits;

- continuous modernization concepts;

- lean machine business concepts;

- towards reconfigurable production systems.

The machine builder has available a table (see Figure 2), where the identified value propositions are reported on the columns and the business needs on the lines. All the business needs fulfilled by each value proposition are highlighted by a coloured box and, among them, the prior ones that can be satisfied through that value proposition have been marked with " $x$ ". For example, if the customer business need is "increase process quality", the most appropriated value proposition to cover this need is "continuous modernisation concepts", as suggested by industrialists. Nevertheless, also "providing availability guarantee" may have impact in the business need response to some extent. As it can be noticed, the proposed methodology does not aim to provide any automatic answer or solution. It constitute a structured support for a conscious decision taking, where resulting options have to be at the end evaluated by machine builder through its experience and according to the specific market situation he is assessing.

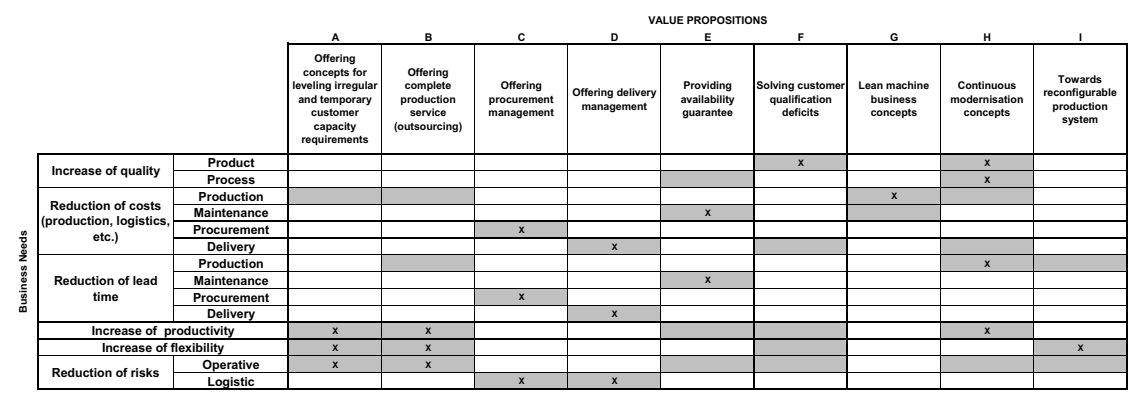

Figure 2. Table supporting the identification of value propositions

\subsection{Definition of cooperation scenarios}

Once identified the value propositions able to respond to customer business needs, the methodology provides some operative addresses to the machine builder in order to shape the relationships and the technology in the business model. With this purpose, the available categorization schemes to configure a business model have been improved and 
the results are shown in Figure 3. The business model can be graphically identified by a line connecting the different options that are chosen for each configuration dimension. The business model configuration dimensions are: responsibility for operating personnel, responsibility for maintenance personnel, production location, payment model, production equipments ownership, production equipment utilization rate, responsibility for raw material procurement, responsibility for final products transportation, equipment technology. Based on the existing literature and on the judgements of machine builder companies, the methodology suggests which are the different types of business models (lines in the table) corresponding to each value proposition, in terms of the possible options for the business model configuration dimensions. As in the previous phase, it is possible that more than one type of business models is associated to a single value proposition. Nevertheless, the attention of machine builder will be restricted on a limited number of possibilities to be evaluated in cooperation with the customer.

\subsection{Testing of the methodology}

The methodology has been applied in real market scenarios that are faced by two leading European machine tool companies. One case was related to a large customer

in the railway sector and the other to a small customer in the moulds and dies industry. The methodology allowed companies to select 3-4 potential cooperation scenarios that will be proposed to the customers and negotiated. Machine tool companies appreciated the structured approach that permitted them to consider all relevant customers' variables in order to identify innovative responses to their needs.

\begin{tabular}{|c|c|c|c|c|c|c|c|c|}
\hline \multirow{2}{*}{\multicolumn{3}{|c|}{$\begin{array}{c}\text { Characteristic features } \\
\text { Operating personnel } \\
\end{array}$}} & \multicolumn{6}{|c|}{ Options } \\
\hline & & & $\begin{array}{c}\text { Equipment } \\
\text { producer }\end{array}$ & \multicolumn{2}{|c|}{$\begin{array}{l}\text { Operating } \\
\text { Joint Venture } \\
\end{array}$} & \multicolumn{2}{|c|}{ Third party } & Customer \\
\hline \multicolumn{3}{|c|}{ Maintenance personnel } & $\begin{array}{c}\begin{array}{c}\text { Equipment } \\
\text { producer }\end{array} \\
\end{array}$ & $\begin{array}{c}\text { Oper } \\
\text { Joint } \\
\end{array}$ & & & & Customer \\
\hline \multicolumn{3}{|c|}{ Location } & $\begin{array}{c}\text { Equipment } \\
\text { producer }\end{array}$ & \multicolumn{2}{|c|}{ Third party } & \multicolumn{2}{|c|}{$\begin{array}{l}\text { "Fence to Fence" } \\
\text { to the customer }\end{array}$} & Customer \\
\hline \multicolumn{3}{|c|}{ Payment modus } & $\begin{array}{c}\text { Pay per } \\
\text { Part } \\
\end{array}$ & $\begin{array}{c}\text { Pay per Use } \\
\text { (Rent) }\end{array}$ & \multicolumn{2}{|c|}{$\begin{array}{c}\begin{array}{c}\text { Pay for } \\
\text { availability }\end{array} \\
\end{array}$} & Fixed rate & $\begin{array}{c}\text { Pay for } \\
\text { equipment }\end{array}$ \\
\hline \multirow{2}{*}{\multicolumn{2}{|c|}{ Ownership }} & $\begin{array}{c}\text { During phase } \\
\text { of use }\end{array}$ & $\begin{array}{l}\text { Equipme } \\
\text { produce }\end{array}$ & & & & & Customer \\
\hline & & $\begin{array}{l}\text { After phase } \\
\text { of use }\end{array}$ & $\begin{array}{l}\text { Equipme } \\
\text { produce }\end{array}$ & & & & & Customer \\
\hline \multicolumn{3}{|c|}{ Utilization rate } & \multicolumn{3}{|c|}{ High } & \multicolumn{3}{|c|}{ Low } \\
\hline \multicolumn{3}{|c|}{ Procurement of raw materials } & $\begin{array}{c}\begin{array}{c}\text { Equipment } \\
\text { producer }\end{array} \\
\end{array}$ & \multicolumn{2}{|c|}{$\begin{array}{l}\text { Operating } \\
\text { Joint Venture }\end{array}$} & \multicolumn{2}{|c|}{ Third party } & Customer \\
\hline \multicolumn{3}{|c|}{ Transport of end products } & $\begin{array}{c}\text { Equipment } \\
\text { producer }\end{array}$ & \multicolumn{2}{|c|}{$\begin{array}{l}\text { Operating } \\
\text { Joint Venture }\end{array}$} & \multicolumn{2}{|c|}{ Third party } & Customer \\
\hline \multirow{6}{*}{ 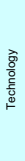 } & & omation level & \multicolumn{3}{|c|}{ High } & \multicolumn{3}{|c|}{ Low } \\
\hline & \multicolumn{2}{|c|}{ Performance level } & \multicolumn{3}{|c|}{ High } & \multicolumn{3}{|c|}{ Low } \\
\hline & \multicolumn{2}{|c|}{ Reconfigurability level } & \multicolumn{3}{|c|}{ High } & \multicolumn{3}{|c|}{ Low } \\
\hline & \multicolumn{2}{|c|}{ Availability (MTTR/MTBF) } & \multicolumn{3}{|c|}{ High } & \multicolumn{3}{|c|}{ Low } \\
\hline & \multicolumn{2}{|c|}{ Complexity level } & \multicolumn{3}{|c|}{ High } & \multicolumn{3}{|c|}{ Low } \\
\hline & & iciency level & & High & & & L & \\
\hline
\end{tabular}

Figure 3. Table supporting the business models configuration

\section{CONCLUSIONS AND FUTURE RESEARCH}

In order to contribute to the development of instruments that can support machine builder companies in the adoption of innovative business models, this paper presented a methodology for the identification of the suited value added cooperation scenarios to be established between customers and equipment suppliers. The starting points of the methodology are customer needs, based on which value propositions and cooperation scenarios are identified. Such a methodology dictates the sequential decision phases that should be faced, it offers diagnostic checklists, some lists of possible options that a machine builder should evaluate, and basic decision criteria that should support the decisions in each phase. The methodology has been developed starting from the literature 
and involving in the research some leading European machine tool companies. For this reason, it is deeply customised for the application in the machine tool sector. The approach has been tested in two real business cases, whose data and information have been provided by two European machine builders. The results have been very useful to better define their strategic market approach and their commercial action.

According to industry needs, further research is needed to continue developing operative tools supporting new strategies implementation. In particular, the development of quantitative instruments assessing the impact of strategic decisions in an economical and environmental life cycle perspective, will be an important goal to be reached in the near future.

\subsection{Acknowledgments}

This work has been partly funded by the European Commission through Project "Next Next Generation Production Systems" (IP 011815 FP6). The authors acknowledge the Commission for its support and Next project partners for their contribution during the development of various ideas and concepts here presented. 


\section{REFERENCES}

1. Cohen MA, Whang S. Competing in Product and Service: A Product Life-Cycle Model. Management Science 1997; Vol. 43, No 4: 535-545.

2. Copani G, Molinari Tosatti L, Lay G, Schroeter M, Bueno R. "New Business Models diffusion and trends in European machine tool industry". Proceedings of the 40th CIRP International Manufacturing Systems Seminar, 2007.

3. Copani G, Molinari Tosatti L, Marvulli S, Groothedde R, Palethorpe D. "New Financial Approaches for the Economic Sustainability in Manufacturing Industry". Proceedings of the 14th CIRP Conference on Life Cycle Engineering, 2007.

4. European Committee for Cooperation of the Machine Tool Industries (Cecimo), www. cecimo.be, 2006 data.

5. Frambach RT, Wels-Lips I, Gündlach A. Proactive Product Service Strategies An Application in the European Health Market. Industrial Marketing Management 1997; Vol. 26: 341-352.

6. Franke C, Seliger G, Hu SJ, Koren Y. "A new paradigm of manufacturing: selling use instead of selling systems". Proceedings of JUSFA Japan-USA Symposium on Flexible Automation, Hiroshima, Japan, 2002.

7. Gebauer H, Fleisch E, Fredli T. Overcoming the Service Paradox in Manufacturing Companies. European Management Journal 2005; Vol. 23, No 1: 14-26.

8. Koren Y, Heisel U, Jovane F, Moriwaki T, Pritschow G, Ulsoy G, Van Brussel H. "Reconfigurable Manufacturing Systems". Annals of the CIRP 1999; Vol. 48/2/1999.

9. Lay G, Meier H, Schramm J, Werding A. Betreiben statt verkaufen - Stand und Perspektiven neuer Geschäftsmodelle für den Maschinen- und Anlagenbau. Industrie Management 2003; 19-4.

10. Lay G., Betreibermodelle fur investitionsuter - Verbreitung, chancen und risiken, erfolgsfactoren, working paper Fraunhofer ISI, Karlsruhe, 2007

11. Mathe H, Portioli Staudacher A. "Innovative Service that Reinvent Manufacturing". IMS International Forum 2004 Global Challenges in Manufacturing, May 17-19, Italy, 2004.

12. Meier H, Kortmann D. "Leadership - From technology to use Operation fields and solution approaches for the automation of service processes of industrial Product-Service Systems". Proceedings of the 14th CIRP Conference on Life Cycle Engineering 2007, pp. 159-163.

13. Oliva R, Kallenberg R. Managing the transition from product to services. International Journal Of Service Industry Management 2003; Vol. 14, No 2: 160-172.

14. Scholz-Reiter B, Krohne F, Severengiz S. "Adaptation Service Manager for Manufacturing Equipment". Proceedings of the 40th CIRP International Manufacturing Systems Seminar, 2007.

15. Seliger G, Consiglio S, Zettl M. "Selling use instead of selling products - Technological and educational enablers for business in ecological product life cycles". In Product Life Cycle Quality Management Issues, 2004.

16. Stollt G. "Development of a Generic Business Model for the European Machine Tool Industry - As part of the foresight activity by Mantys". Mantys report 2005, pp. 8-27.

17. Urbani A, Molinari Tosatti L, Pasek Z. "Manufacturing practices in dynamic markets: reconfigurability to enable a service-based manufacturing capacity supply". Proceedings of the ASME-IMECE International Mechanical Engineering Congress and Exposition, New Orleans, Louisiana, November 17-22, 2002.

18. Urbani A, Molinari Tosatti L, Pierpaoli F, Jovane F. "New frontiers for manufacturing in Mass customization". The 35th CIRP, May 12-15, Korea, 2002.

19. Windahl C, Andersson P, Berggre C, Nehler C. "Manufacturing firms and integrated solutions: characteristics and implications". European Journal of Innovation Management 2004; Vol. 7, No 3: 218 228.

20. www.european-manufacturing-survey.eu 